\title{
hooks kirjoittaa niin kuin opettaa ja elää
}

hooks, bell 2007. Vapauttava kasvatus. Suom. Jyrki Vainonen. Toim. Hilkka Rekola ja Marjo Vuorikoski. Alkuperäinen teos Teaching to transgress - Education as the practice of freedom (1994). Helsinki: Kansanvalistusseura. 303 sivua.

\section{$\mathrm{M}$} eillä Suomessa on vahva vapaan sivistystyön perinne, mutta tunnemme yllättävän huonosti muun maailman vastaavia tai radikaaleja aikuiskasvatusperinteitä. bell hooksin kirja Vapauttava kasvatus tuo yhden tarpeellisen näkökulman, joka auttaa omien ja muualla kehitettyjen kasvatustieteellisten perinteiden vertailussa.

bell hooks, ristimänimeltään Gloria Watkins, on amerikanafrikkalainen feministiteoreetikko, joka on kirjoittanut paljon kasvatuksesta. Vapauttava kasvatus on tärkeä panos kriittisen ja vapauttavan sekä sukupuolija rotusensitiivisen kasvatustieteellisen teorian ja kielen kehittämiseksi myös Suomessa. Teos liittyy kasvatusfilosofiseen ja teoreettiseen perinteeseen, jossa on korostettu yksilön ja yhteisöjen omaperäisten (ei ylhäältä annettujen tai valtiojohtoisten) toimintamahdollisuuksien kasvattamiseen. Kirja koostuu erillisistä ja erilaisiin tarkoituksiin kirjoitetuista teksteistä, jotka kuitenkin yhdessä muodostavat eheän kokonaisuuden.

Yhdysvalloissa hooksilla on jo pitkään ollut oma monitieteinen lukija- ja ihailijakuntansa, joka on kiinnostunut paitsi rotukysymyksestä myös pedagogiikasta ja kasvatuksesta. Suomalaiselle lukijalle ehkä uusinta ovat kirjan monikulttuuriset ja etniset painotukset, keskustelu rodusta, sekä hooksin tapa kirjoittaa hyvin oma- ja henkilökohtaisessa sävyssä.

\section{Teos oli itselleni keskustelukumppani}

hooksin kirja oli itselleni aikanaan tärkeä keskustelukumppani opiskellessani niin kutsuttua kriittistä pedagogiikkaa ja kehitellessäni omaa näkökulmaani siihen. Teos toi vahvasti esiin rotuja sukupuolikysymyksen, sen mitä on olla musta akateeminen nainen Yhdysvalloissa ja opiskella ja opettaa yliopistossa, ja auttoi havaitsemaan ihmisten välisiin rodullisiin, sukupuolisiin ja heidän luokkataustaansa liittyviä kysymyksiä. Sen avulla saattoi tarkastella eroja, mutta etsiä myös yhtäläisyyksiä, yhteistä ihmisyyttä ja tasa-arvoisten erilaisuutta.

Alkukielisen teoksen lukemisestani on jo aikaa, sillä muistan tarttuneeni siihen tuoreeltaan vuonna 1994. Nuorelle työläistaustasta tulevalle valkoiselle heterolle lukukokemus oli palkitseva ja opettavainen. Kirjan kieli oli suhteellisen helppoa taitaa ja tyyli veti mukaansa. Ihailin hooksin tapaa laittaa itsensä likoon, ja ihailen yhä: hän kirjoittaa kuten opettaa, ja kuten elää. Porvarillisin mittarein hän on saavuttanut paljon. Päässyt huippuyliopistoihin, valmistunut huippuarvosanoin ja saanut pysyviä virkoja. Mutta hän on myös osannut luopua näistä saavutuksista, mikä lienee vaikeinta. Nykyisin hooks on vapaa kirjoittaja, joka ottaa harkitusti vierailevan asiantuntijan pestejä yliopistojen naistutkimuksen ja kirjallisuuden koulutusohjelmista.

Kirjan teksteissä näkyy hook- 
sin tavoite kasvaa omaksi itsekseen ja rohkaista opiskelijoita samaan. Hän ei liioittele eikä kauppaa ajatuksiaan, vaan kuvaa oman henkilökohtaisen kokemuksensa kautta opiskelun ja opettamisen iloja ja ongelmia. Kirjan sanoma on ajankohtainen omassa toimintaympäristössäni yliopistossa. hooksin opiskelijat vaativat yliopistopedagogiikalta paljon: henkilökohtaisuutta, syvyyttä, tasapuolisuutta, demokraattisuutta. Vaatimukset ovat kasvaneet myös meillä. Toisaalta halutaan (ja tarjotaan) runsaasti ohjausta ja neuvontaa melkeinpä kädestä pitäen, mutta toisaalta vaaditaan tehokkuutta sekä käytännöllisyyttä, tai kasvatustieteellisten opintojen "työelämävastaavuutta". Tätä jälkimmäistä opiskelijoiden ja hallinnon taholta esitettyä vaatimusta olen ihmetellyt sekä yleisesti, uuden kapitalismin lyhytnäköisyyden kannalta, että korkeakoulupedagogisesti.

Kannustaessani peruskurssini opiskelijoita opiskelemaan kurssikirjallisuutta tentin sijasta opintopiirissä olen huomannut perustelevani asiaa hyötynäkökulmasta: opintopiirissä opitte monen moista työelämässä vaadittavaa ja käyttökelpoista kirjoittamisesta keskustelemiseen ja ajatustenvaihtoon, ryhmätyöhön ja toisten kuuntelemiseen. Myös hooks pohtii kysymystä vapauttavien opetuskäytäntöjen näkökulmasta, muttei lankea tapaiseeni lirkutteluun (ass kissing) vaan rohkaisee koskettavaan pedagogiikkaan painottaen ajatusta: "Vain ruumiillaan näkee hyvin”, käyttääkseni kirjailija Kristiina Wallinin sanoja.

Vapauttava kasvatus liikkuu useilla ajallisilla tasoilla yhdistellen kirjoittajansa muistoja ja kokemuksen rakenteita pedagogisiin kysymyksiin, mikä lisää tekstin mielenkiintoa ja luettavuutta. Sen avulla voi tunnistaa omia lapsuus-, nuoruus- ja aikuisiän kasvu- ja kasvatuskokemuksia, ja liittää niitä kasvatusjärjestelmän antamiin vapauksiin ja sen asettamiin pakkoihin.

Vaikka suomennoksen lukeminen oli monessakin suhteessa hyvin erilainen kokemus nyt kuin joskus 1990-luvun puolivälissä, tunnistan käännöksestä hooksin tyylin ja hänen ajatustensa henkilökohtaisen koskettavuuden. Käännös säilyttää alkuperäisen tekstin oleelliset sävyt. Kirja palauttaa mieleeni tiettyjä kriittisen pedagogiikan peruskysymyksiä; esimerkiksi opettajan merkityksestä, tai itsensä panemisesta peliin, avaten niitä nyt kuitenkin laajemmin tai syvemmin kuin vuosikymmen sitten siinä yhä kovenevassa akateemisessa maailmassa, jonka työssäni miltei päivittäin kohtaan. Kirjan keskivaiheen luvut 5, 6 ja 7 jääväät itselleni edelleen etäisiksi, mutta palvelevat ennen kaikkea naistutkimuksen teoriasta kiinnostunutta lukijaa.

\section{Osallistavaa \\ pedagogiikkaa}

Tällaista hooksin antamaa mallia ajatella, kirjoittaa ja opettaa me Suomessakin kai kaipaisimme, huippuyliopistohuuman vastapainoksi, sillä vielä meillä ei vielä ole kieltä asioiden omakohtaiseen, kokemukselliseen tai ruumiilliseen kasvatustieteelliseen ilmaisemiseen. Hänen kaltaistaan kirjoittajaa tarvittaisiin kai siksikin, ettemme hukkuisi ylitsepursuavaan itseriittoisuuteemme, tartuttaisi sitä opiskelijoihimme ja lopulta infektoisi koko maailmaa tämän pienen ja pohjoisen tehoyhteiskuntamme huippuosaamisslangilla tai uudella ulkopoliittisella hölynpölyllä.

Suomessa hooksin kirjan kohderyhmää ovat laajasti ottaen kaikki kasvattajat, mutta erityisesti opettajankouluttajat ja aikuiskasvattajat. Kirja sopii kurssikirjaksi kasvatustieteellisiin ja aikuiskasvatustieteellisiin koulutusohjelmiin. Jyrki Vainosen suomennos on mutkaton, vaikka käännöksistä voisi jossitella kai loputtomiin. Kirjan toimittajat ovat tehneet naisen työn auttaessaan käännöstyössä.

Kansanvalistusseuran kannattaa käännöskirjallisuuden osalta jatkossakin panostaa kustannustoiminnassaan nimenomaan sellaisten kirjojen suomentamiseen, kuten hooks, jotka liittyvät suomalaisen vapaan sivistystyön perinteeseen sitä laajentaen ja edelleen kehittäen. Tässä mielessä toinen, monella tavalla harkinnanarvoinen käännösteko olisi aikuiskasvatuksen tunnetun teoreetikon Stephen Brookfieldin (ks. hänen haastattelunsa Aikuiskasvatus 3/2006) pääteoksen The Power of Critical Theory suomentaminen.

\section{Juha Suoranta}

